\title{
Chapter 19 \\ Geographical and Seasonal Variations of the Shell Microstructures in the Bivalve Scapharca broughtonii
}

\author{
Kozue Nishida and Takenori Sasaki
}

\begin{abstract}
Cyclical ontogenetic changes of shell microstructures have been observed in the subfamily Anadarinae (Mollusca: Bivalvia, Arcidae) including fossil taxa. The changes in the bloody clam Scapharca broughtonii are controlled by temperature, which fluctuates seasonally, and can be used to determine the age of the individuals and to reconstruct paleoenvironments. In this study, samples of $S$. broughtonii from eight localities covering broad geographical regions at various latitudes in Japan, Korea, and Russia were examined to assess the utility of time series variations in microstructures for paleoenvironmental and paleoecological studies. All specimens showed cyclical changes in the relative thickness of the composite prismatic and crossed lamellar structures in the outer layer with ontogenetic progression, and thus, this feature can be used as a proxy for water temperature of their habitats. Specimens from southern latitudes showed higher annual shell growth rates than northern specimens, suggesting that low temperatures arrest shell growth in $S$. broughtonii and play a key role in determining the longevity and body size in $S$. broughtonii. In long-lived individuals from the four northernmost localities, the relative thickness of the composite prismatic structure tended to decrease as the individuals aged, which may be a consequence of declining physiological activity, such as organic matrix secretion.
\end{abstract}

Keywords Shell microstructure $\cdot$ Geographic variation $\cdot$ Water temperature Growth rate $\cdot$ Age determination $\cdot$ Bivalve $\cdot$ Scapharca broughtonii $\cdot$ Temperate species

\footnotetext{
K. Nishida $(\square)$

Ibaraki College, National Institute of Technology, Ibaraki, Japan

Japan Society for the Promotion of Science (JSPS), Tokyo, Japan

e-mail: nishida@gm.ibaraki-ct.ac.jp

T. Sasaki
}

The University Museum, The University of Tokyo, Bunkyo-ku, Tokyo, Japan

e-mail: sasaki@um.u-tokyo.ac.jp 


\subsection{Introduction}

Shell microstructures of molluscs are highly diversified (Carter 1990), and the shell microstructures formed by a single individual can differ, depending on phylogenetic (Taylor et al. 1969; Shimamoto 1986; Sato and Sasaki 2015), crystallographic (Ubukata 2001; Checa et al. 2009, 2013), and environmental (Carter 1980; Kennish 1980; Lutz and Clark 1984) factors. Recently, Nishida et al. (2012) reported seasonal changes in the relative thickness of the two microstructures (composite prismatic and crossed lamellar structures) in the outer layer of the bloody clam Scapharca broughtonii. The composite prismatic and crossed lamellar structures of the outer layer are formed on the exterior and interior sides, respectively (Fig. 19.1), with the composite prismatic structure being thicker at lower water temperatures (Nishida et al. 2012). Nishida et al. (2015) observed shell microstructures in cultured specimens of $S$. broughtonii reared at five different temperatures, demonstrating experimentally the thermal dependency of the mode of shell microstructural formation in this species. Cyclical changes in microstructures with ontogeny have been observed in the subfamily Anadarinae (Mollusca: Bivalvia, Arcidae), including fossil taxa (Kobayashi and Kamiya 1968; Kobayashi 1976a, 1976b; Nishida et al. 2012), and can be useful for age determination and temperature reconstruction. Knowledge on geographical variations in shell microstructural formation in $S$. broughtonii remains limited (Nishida et al. 2012). Thus, samples of S. broughtonii were collected for this study from eight localities at various latitudes in Japan, Russia, and Korea to assess the utility of the cyclic thickness fluctuation in shell microstructures in paleoenvironmental and paleoecological studies.

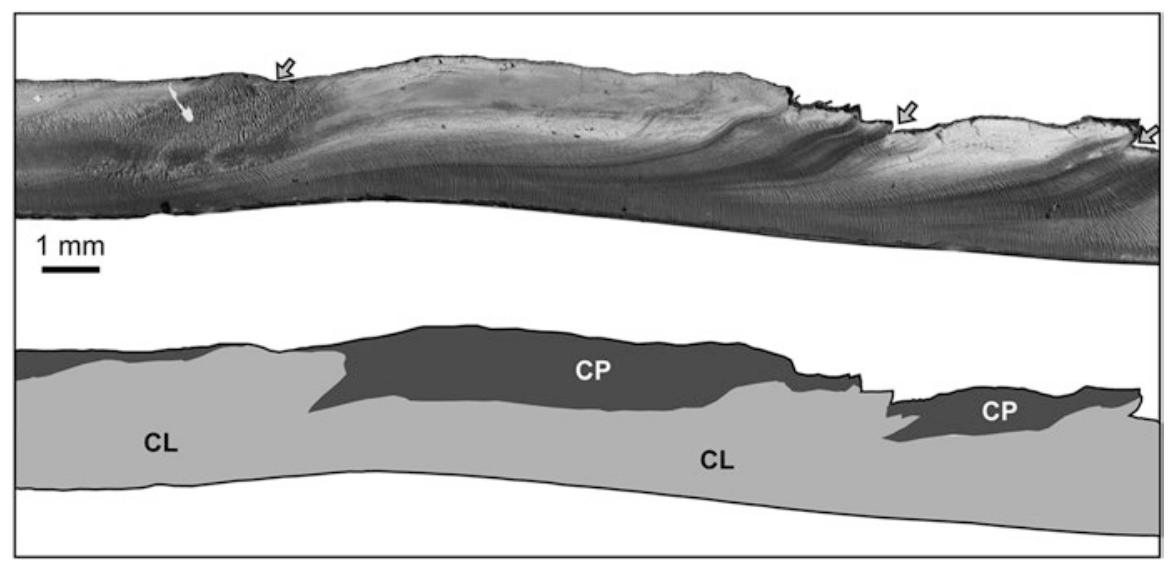

Fig. 19.1 An optical micrograph of the acetate peel of radial section of the outer layer near the outer shell margin in the specimen SB-IN3-01 collected at locality 4 . With the growth toward to the right, fluctuations are observed in the relative thickness of the composite prismatic and crossed lamellar structures of the outer layer. Gray arrows indicate growth breaks. Abbreviations: CL, crossed lamellar layer; $\mathrm{CP}$, composite prismatic layer 


\subsection{Materials and Methods}

We examined S. broughtonii shells collected from six sites in Japan (Localities 1, 2, 4, 5, 7, 8), one site in Russia (Locality 3), and one site in Korea (Locality 6) (Table 19.1, Fig. 19.2). Of the 12 specimens collected from Localities 2-6 and 8, 9 were collected by dredge operations, and the remaining 3 specimens were likely collected also by dredging. The specimens at Locality 1 were cultured in a net, and the specimens at Locality 7 were cultured in a cage. Shell microstructures of those 14 specimens were prepared by the acetate peel method (Kennish et al. 1980), and then the thickness of the composite prismatic and crossed lamellar structures and the total thickness of the outer layer were measured at approximately 1-mm intervals following Nishida et al. (2012) with ImageJ/NIH image analysis software (version 1.45; http://imagej.nih.gov/ij/). Data of three specimens from Localities 1, 2, and 7 (SB-MT3, SB-YR-101-1, and SB-KM10b-2, respectively) reported in Nishida et al. (2012) were used for comparison with the data obtained in this study. According to Nishida et al. (2012), the age of each individual could be estimated by the number of the growth break (summer break) intervals and the positive peaks observed in the relative thickness of the crossed lamellar structure.

\subsection{Results}

The relative thickness of the composite prismatic and crossed lamellar structures in the outer layer of each specimen changed cyclically with ontogeny (Figs. 19.2 and 19.3). The ratio of the composite prismatic structure thickness to the total outer layer thickness was $0 \%$ at the minimum and had a maximum value as high as 58-80\% (Figs. 19.2 and 19.3). For all specimens, the intervals between the cycle of relative thickness fluctuation of the two structures shortened with ontogeny, and the range of fluctuation in the relative thickness of the composite prismatic structure decreased in specimens older than 4 years (Figs. 19.2 and 19.3). In the specimens from Vladivostok (SB-RU11-01, SB-RU11-02; Fig. 19.2), the relative thickness of the composite prismatic structure fluctuated seasonally during earlier growth stages, while the fluctuations became smaller at later growth stages until the cyclic changes in the relative thickness became almost indiscernible.

To examine the variations in annual growth of individuals from the same localities, we compared at least two specimens each for four localities (Localities 1-3, 7; Figs. 19.3 and 19.4). Individuals cultured in the same cage at Locality 7 showed a similar pattern of microstructural changes (Fig. 19.3c, d). In contrast, growth patterns of the individuals cultured at Locality 1 showed considerable variations (Fig. 19.3a, b).

Growth curves for the specimens from the eight localities are shown in Fig. 19.2. The annual shell growth rate was higher in the specimens from southern localities than in those from northern localities, corresponding to the general increase in water 
Table 19.1 Specimens of $S$. broughtonii examined in this study. All specimens are registered at the Department of Historical Geology and Paleontology, University Museum, The University of Tokyo (UMUT). Asterisks indicate specimens reported by Nishida et al. (2012); specimens 1, 2a, 2b, 3a, and 3b in Nishida et al. (2012) are identified as specimens SB-MT3, SB-YU101-1, SB-YR102-4, SB-KM10b-2, and SB-KM10b-3, respectively, in this study

\begin{tabular}{|c|c|c|c|c|c|c|c|}
\hline $\begin{array}{l}\text { Locality } \\
\text { number }\end{array}$ & $\begin{array}{l}\text { Sampling } \\
\text { site }\end{array}$ & $\begin{array}{l}\text { Sampling } \\
\text { method }\end{array}$ & Depth & $\begin{array}{l}\text { Collection } \\
\text { date }\end{array}$ & \begin{tabular}{|l|} 
Number \\
of \\
specimens
\end{tabular} & $\begin{array}{l}\text { Specimen } \\
\text { number }\end{array}$ & $\begin{array}{l}\text { Collection } \\
\text { number }\end{array}$ \\
\hline \multirow[t]{2}{*}{$\begin{array}{l}\text { Locality } \\
1\end{array}$} & \multirow{2}{*}{$\begin{array}{l}\text { Mutsu Bay, } \\
\text { Aomori } \\
\text { Prefecture }\end{array}$} & \multirow[t]{2}{*}{$\begin{array}{l}\text { Cultured } \\
\text { in net }\end{array}$} & \multirow[t]{2}{*}{$5-10 \mathrm{~m}$} & \multirow{2}{*}{\begin{tabular}{|l|}
20 \\
September \\
2010
\end{tabular}} & \multirow[t]{2}{*}{$N=2$} & SB-MT3* & $\begin{array}{l}\text { UMUT } \\
\text { RM31012 }\end{array}$ \\
\hline & & & & & & SB-MT4 & $\begin{array}{l}\text { UMUT } \\
\text { RM32670 }\end{array}$ \\
\hline \multirow[t]{6}{*}{$\begin{array}{l}\text { Locality } \\
2\end{array}$} & \multirow{3}{*}{$\begin{array}{l}(2-1) \text { at } \\
38^{\circ} 05^{\prime} \mathrm{N}, \\
140^{\circ} 58^{\prime} \mathrm{E}, \\
\text { Miyagi } \\
\text { Prefecture, } \\
\text { in the } \\
\text { Pacific } \\
\text { Ocean }\end{array}$} & \multirow[t]{3}{*}{ Dredge } & \multirow[t]{3}{*}{$\begin{array}{l}22- \\
23 \mathrm{~m}\end{array}$} & \multirow{3}{*}{$\begin{array}{l}28 \\
\text { December } \\
2010\end{array}$} & \multirow[t]{3}{*}{$N=3$} & SB-YR101-1* & $\begin{array}{l}\text { UMUT } \\
\text { RM31013 }\end{array}$ \\
\hline & & & & & & SB-YR101-4 & $\begin{array}{l}\text { UMUT } \\
\text { RM32671 }\end{array}$ \\
\hline & & & & & & SB-YR101-11 & $\begin{array}{l}\text { UMUT } \\
\text { RM32672 }\end{array}$ \\
\hline & \multirow{3}{*}{$\begin{array}{l}(2-2) \text { at } \\
38^{\circ} 09^{\prime} \mathrm{N}, \\
140^{\circ} 59^{\prime} \mathrm{E}, \\
\text { Miyagi } \\
\text { Prefecture, } \\
\text { in the } \\
\text { Pacific } \\
\text { Ocean }\end{array}$} & \multirow[t]{3}{*}{ Dredge } & \multirow[t]{3}{*}{$\begin{array}{l}22- \\
23 \mathrm{~m}\end{array}$} & \multirow{3}{*}{$\begin{array}{l}28 \\
\text { December } \\
2010\end{array}$} & \multirow{3}{*}{$N=3$} & SB-YR102-2 & $\begin{array}{l}\text { UMUT } \\
\text { RM32673 } \\
\end{array}$ \\
\hline & & & & & & SB-YR102-4* & $\begin{array}{l}\text { UMUT } \\
\text { RM31014 }\end{array}$ \\
\hline & & & & & & SB-YR102-9 & $\begin{array}{l}\text { UMUT } \\
\text { RM32674 }\end{array}$ \\
\hline \multirow[t]{2}{*}{$\begin{array}{l}\text { Locality } \\
3\end{array}$} & \multirow{2}{*}{$\begin{array}{l}\text { Off } \\
\text { Vladivostok, } \\
\text { Sea of Japan }\end{array}$} & \multirow{2}{*}{ Dredge? } & \multirow[t]{2}{*}{-} & \multirow[t]{2}{*}{ July 2011} & \multirow[t]{2}{*}{$N=2$} & SB-RU11-01 & $\begin{array}{l}\text { UMUT } \\
\text { RM32675 }\end{array}$ \\
\hline & & & & & & SB-RU11-02 & $\begin{array}{l}\text { UMUT } \\
\text { RM32676 }\end{array}$ \\
\hline $\begin{array}{l}\text { Locality } \\
4\end{array}$ & $\begin{array}{l}\text { Nanao Bay, } \\
\text { Ishikawa } \\
\text { Prefecture, } \\
\text { Sea of Japan }\end{array}$ & Dredge & $30 \mathrm{~m}$ & $\begin{array}{l}01 \\
\text { November } \\
2011\end{array}$ & $N=1$ & SB-IN3-01 & $\begin{array}{l}\text { UMUT } \\
\text { RM32677 }\end{array}$ \\
\hline \multirow[t]{2}{*}{$\begin{array}{l}\text { Locality } \\
5\end{array}$} & \multirow{2}{*}{$\begin{array}{l}\text { Kohama } \\
\text { Bay, Fukui } \\
\text { Prefecture, } \\
\text { Sea of Japan }\end{array}$} & \multirow[t]{2}{*}{ Dredge } & \multirow[t]{2}{*}{$4-5 \mathrm{~m}$} & \multirow{2}{*}{$\begin{array}{l}24-27 \\
\text { February } \\
2011\end{array}$} & \multirow[t]{2}{*}{$N=2$} & SB-FK1 & $\begin{array}{l}\text { UMUT } \\
\text { RM32678 }\end{array}$ \\
\hline & & & & & & SB-FK2 & $\begin{array}{l}\text { UMUT } \\
\text { RM32679 }\end{array}$ \\
\hline $\begin{array}{l}\text { Locality } \\
6\end{array}$ & $\begin{array}{l}\text { Jinhae-gu, } \\
\text { Sea of } \\
\text { Japan, } \\
\text { Korea } \\
\end{array}$ & Dredge? & - & $\begin{array}{l}\text { 29 June } \\
2011\end{array}$ & $N=1$ & SB-KOT-3 & $\begin{array}{l}\text { UMUT } \\
\text { RM32680 }\end{array}$ \\
\hline
\end{tabular}


Table 19.1 (continued)

\begin{tabular}{|c|c|c|c|c|c|c|c|}
\hline $\begin{array}{l}\text { Locality } \\
\text { number }\end{array}$ & $\begin{array}{l}\text { Sampling } \\
\text { site }\end{array}$ & $\begin{array}{l}\text { Sampling } \\
\text { method }\end{array}$ & Depth & $\begin{array}{l}\text { Collection } \\
\text { date }\end{array}$ & $\begin{array}{l}\text { Number } \\
\text { of } \\
\text { specimens }\end{array}$ & $\begin{array}{l}\text { Specimen } \\
\text { number }\end{array}$ & $\begin{array}{l}\text { Collection } \\
\text { number }\end{array}$ \\
\hline \multirow[t]{2}{*}{$\begin{array}{l}\text { Locality } \\
7\end{array}$} & \multirow{2}{*}{$\begin{array}{l}\text { At } 33^{\circ} 58^{\prime} \\
\mathrm{N}, 131^{\circ} 50^{\prime} \\
\text { E off } \\
\text { Kudamatsu } \\
\text { city, } \\
\text { Yamaguchi } \\
\text { Prefecture, } \\
\text { in the Seto } \\
\text { Island Sea }\end{array}$} & \multirow[t]{2}{*}{$\begin{array}{l}\text { Cultured } \\
\text { in cage }\end{array}$} & \multirow[t]{2}{*}{$10 \mathrm{~m}$} & \multirow{2}{*}{$\begin{array}{l}22 \\
\text { December } \\
2010\end{array}$} & \multirow[t]{2}{*}{$N=2$} & SB-KM10b-2* & $\begin{array}{l}\text { UMUT } \\
\text { RM31015 }\end{array}$ \\
\hline & & & & & & SB-KM10b-3* & $\begin{array}{l}\text { UMUT } \\
\text { RM31016 }\end{array}$ \\
\hline $\begin{array}{l}\text { Locality } \\
8\end{array}$ & $\begin{array}{l}\text { Tachibana } \\
\text { Bay, } \\
\text { Nagasaki } \\
\text { Prefecture }\end{array}$ & Dredge & $\begin{array}{l}22- \\
23 \mathrm{~m}\end{array}$ & $\begin{array}{l}11 \\
\text { January } \\
2011\end{array}$ & $N=1$ & SB-NT1 & $\begin{array}{l}\text { UMUT } \\
\text { RM32681 }\end{array}$ \\
\hline
\end{tabular}

temperature (Figs. 19.1, 19.4 and 19.5). Nishida et al. (2012) reported that shell growth of the field-collected specimens of $S$. broughtonii was probably arrested at temperatures below $12{ }^{\circ} \mathrm{C}$. The length of time in a year when the water temperature was above $12{ }^{\circ} \mathrm{C}$ was longer in the south than in the north (Fig. 19.2b).

\subsection{Discussion}

All specimens showed cyclical ontogenetic changes in the relative thickness of the two structures (composite prismatic and crossed lamellar structures) in the outer shell layer. Thus, this character of shell microstructure in this species can be applied as a proxy of water temperature in different geographic regions. The annual shell growth rate was higher in southern specimens than in northern specimens (Fig. 19.5), probably due to the shorter duration of temperatures below $12{ }^{\circ} \mathrm{C}$, a temperature range in which shell growth is reported to be arrested (Nishida et al. 2012). The specimens from Locality 8 (water temperature range $16-26^{\circ} \mathrm{C}$ ) probably grew all year round. On the other hand, the specimens from Locality $4\left(0-25^{\circ} \mathrm{C}\right)$ may form shells only for a period of approximately 4 months. Thus, low temperatures below $12{ }^{\circ} \mathrm{C}$ are suggested to play a key role in the longevity and shell size in $S$. broughtonii.

Nishida et al. (2015) suggested that the faster growth at lower temperatures is achieved by dominantly building the composite prismatic structure, probably as an adaptive strategy to precipitate shells under cold water environments. However, as the composite prismatic structure is physically weaker than the crossed lamellar structure (Taylor and Layman 1972; Currey 1976), it is disadvantageous for maintaining the shell mechanical strength. Thus, a trade-off between growth and physical characteristics (e.g., strength) should be considered in investigations of thermal 

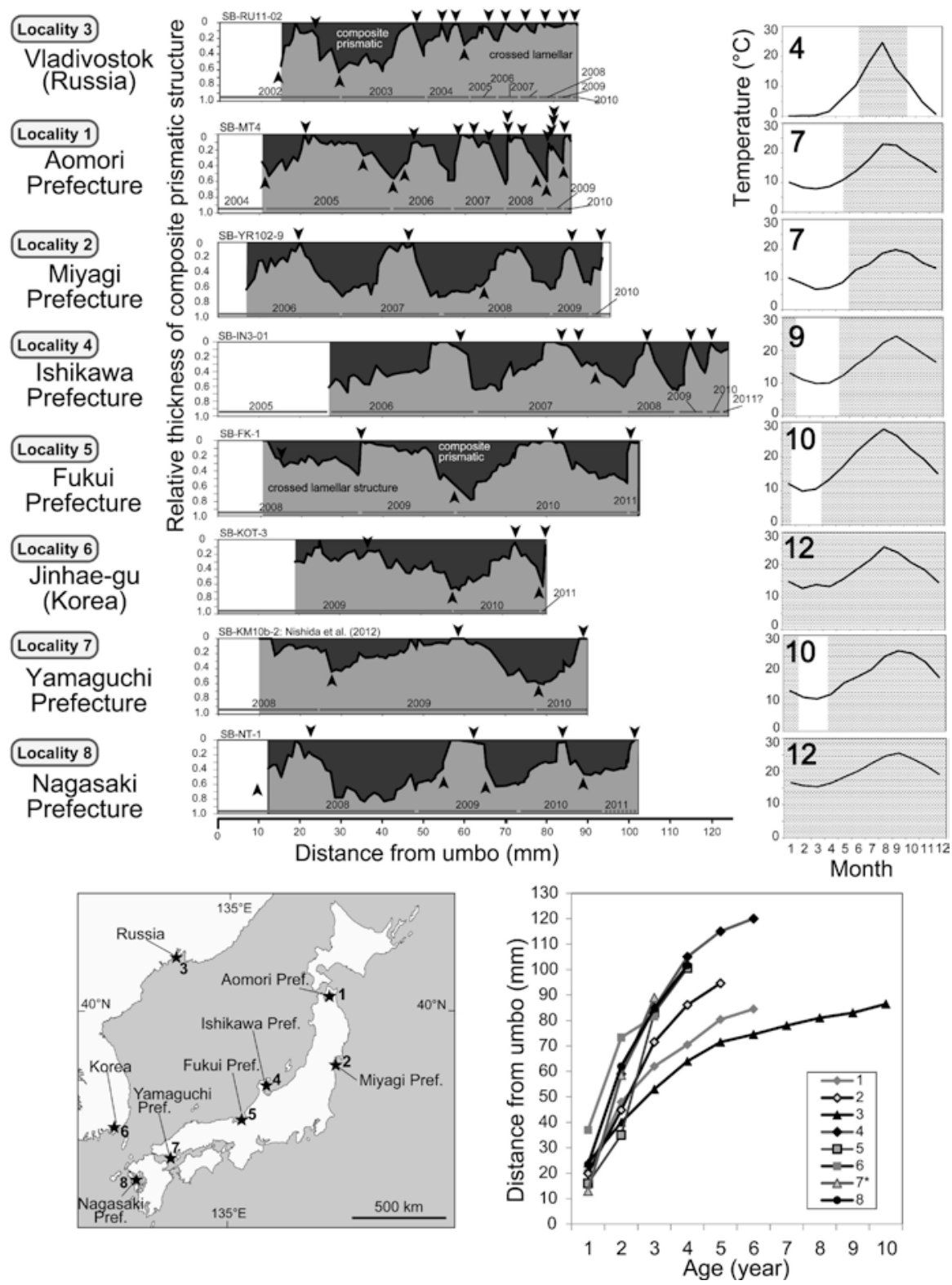

Fig. 19.2 The growth curves and changes in the relative thickness of the two structures in the outer layer at eight localities arranged from north to south along the coasts of Japan, Russia, and Korea. Arrow heads indicate growth breaks; black, gray, and white areas indicate composite prismatic structure, crossed lamellar structure, and missing sections of the outer layer, respectively, and the growth years are indicated by horizontal bars. The water temperature data are from the Japan Oceanographic Data Center (JODC, http://www.data.jma.go.jp/obd/stats/etrn/index.php). Water temperature at each of the eight localities is shown with gray shading on months with water temperature above $12{ }^{\circ} \mathrm{C}$ and the number indicating the number of months with water temperature above $12{ }^{\circ} \mathrm{C}$. The growth curve of Locality 7 is for the reference specimen cited from Nishida et al. (2012) 

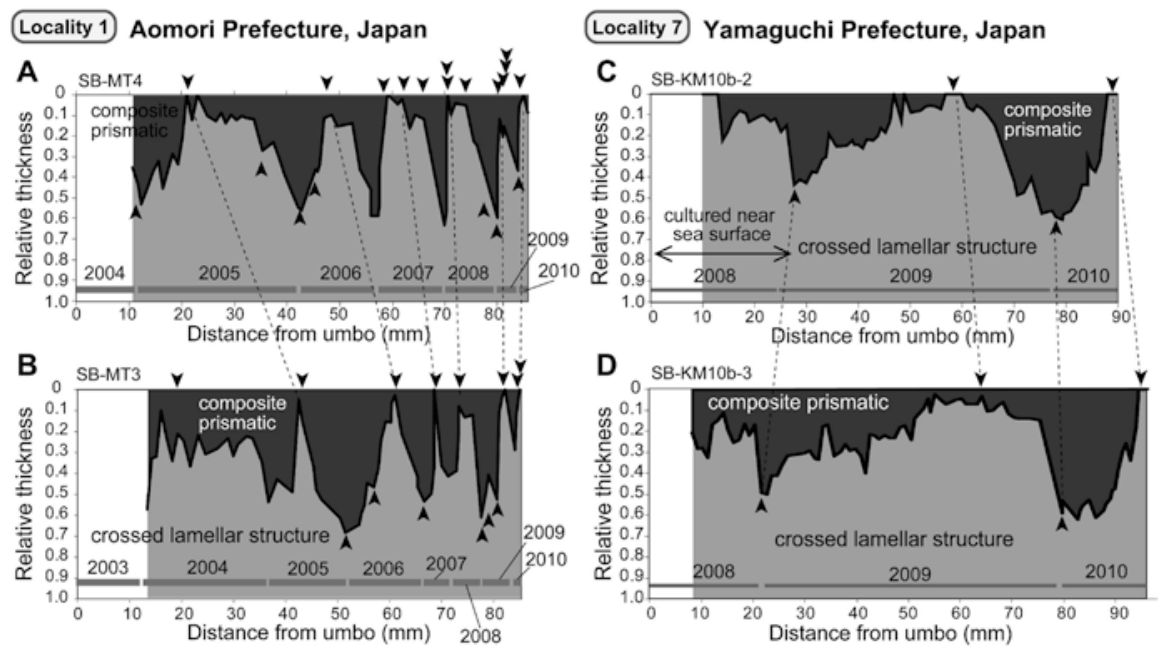

Fig. 19.3 Differences in shell microstructural records between two cultured individuals reared in the same localities. (a) Specimen SB-MT4 at Locality 1. (b) Specimen SB-MT3 at Locality 1, reported by Nishida et al. (2012). (c) Specimen SB-KM10b-2 at Locality 7, reported by Nishida et al. (2012). (d) Specimen SB-KM10b-3 at Locality 7. Arrows indicate growth breaks in the outer shell surface; black, gray, and white areas indicate composite prismatic structure, crossed lamellar structure, and missing sections of the outer layer, respectively
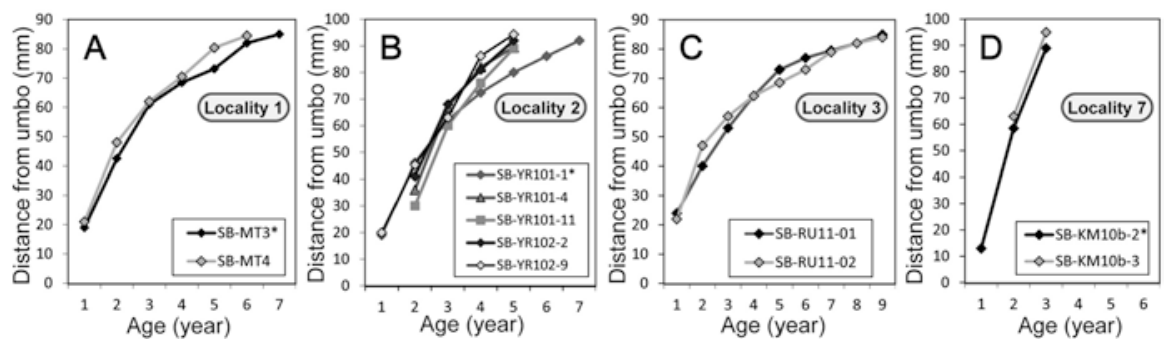

Fig. 19.4 Growth curves of the specimens from Localities 1, 2, 3, and 7 drawn based on the intervals of the summer growth breaks and the positive peaks in the thicknesses of the crossed lamellar structure. Asterisks indicate specimens reported by Nishida et al. (2012); specimens 1, 2a, and 3a in Nishida et al. (2012) are identified as specimens SB-MT3, SB-YU101-1, and SB-KM10b-2, respectively, in this study. (a) Specimens SB-MT3 and SB-MT4 from Locality 1. (b) Specimens SB-YR101-1, SB-YR101-4, SB-YR101-11, SB-YR102-2, and SB-YR102-9 from Locality 2. (c) Specimens SB-RU11-01 and SB-RU11-02 from Locality 3. (d) Specimens SB-KM10b-2 and SB-KM10b-3 from Locality 7

adaptation of microstructures in molluscs. The growth strategy of S. broughtonii inferred by shell growth patterns and microstructures (e.g., to reach a larger body size and/or maturity faster) might be important in the growth stage before maturity. In long-lived specimens from Localities 1-4, the relative thickness of the composite prismatic structure tended to decrease as the individuals aged (Figs. 19.2 and 19.3). 


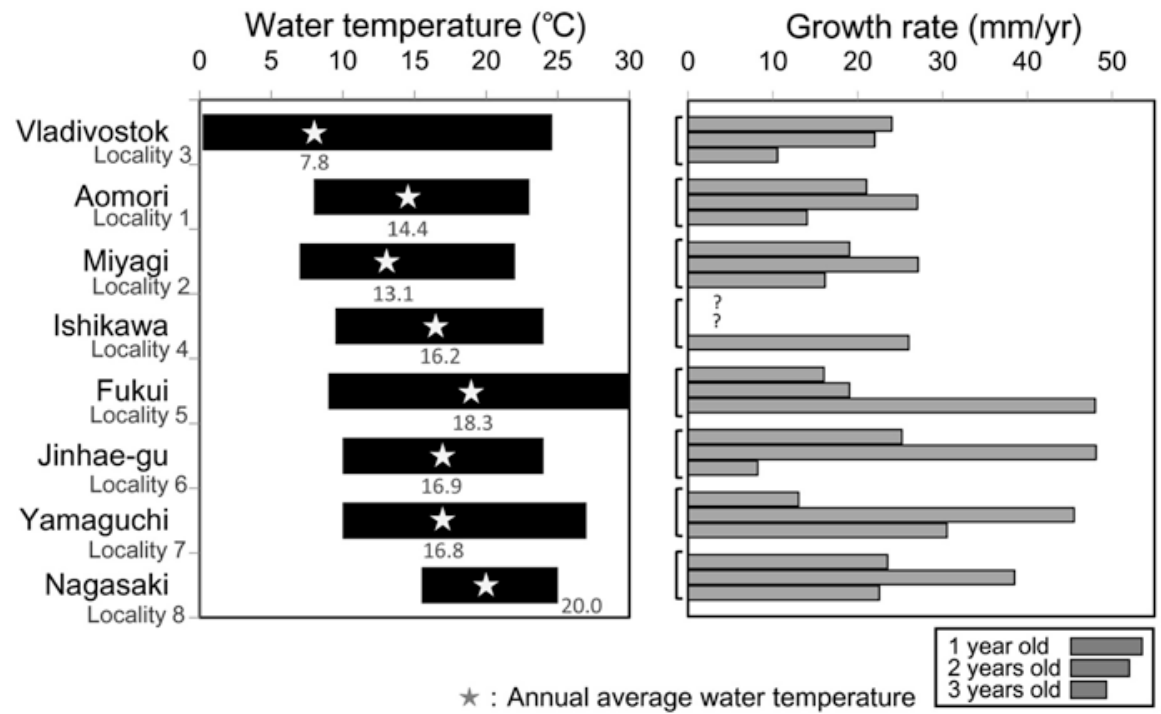

Fig. 19.5 Observed water temperature and estimated annual shell growth rates at eight localities arranged from north to south. The temperature data are from the Japan Oceanographic Data Center (JODC, http://www.data.jma.go.jp/obd/stats/etrn/index.php). The average annual seawater temperature at the eight localities approximately ranges from 7.8 to $20.0{ }^{\circ} \mathrm{C}$. Annual shell growth rate was estimated from growth curves in Fig. 19.2. Annual growth rates of 1- and 2-year-old specimens at Locality 4 were not estimated because no summer growth break was observed in the shell surface of the 1-year-old specimen

Although the primary factor controlling the relative thickness of the two structures in the outer layer would be the seasonal changes in water temperature, physiological factors related to aging may also control microstructural formation in S. broughtonii. Palmer (1983) suggested that the cost of shell production is cheaper in organicrich shells than in organic-poor shells. Composite prismatic structure in bivalve shells is richer in organics than is the crossed lamellar structure (Taylor and Layman 1972; Nishida et al. 2015) and, thus, after sexual maturity, a decrease in the volume of composite prismatic structure in shells may be accompanied by a decline in physiological activity, such as organic matrix secretion. Age-related changes in shell microstructures may show a trade-off between growth and physiological factors attributable to aging. At later growth stages of the individuals from Locality 3, the relative thickness of the composite prismatic structure became thinner with aging until cyclic changes in the relative thickness were almost indiscernible. Because this region is in the northern limit for this species, energetic cost might be needed not only for shell microstructural formation but also other physiological demands.

Differences observed in cultivation experiments may also have some effect. Patterns of the relative thickness of the two shell structures were more variable in the specimens from Locality 1 , where they were cultured in a net hanging in the water column above the seafloor than in those from Locality 7, where they were cultured in a cage resting on the bottom sediment. Yurimoto et al. (2007) reported a 
lower monthly shell growth rate in the individuals of Scapharca kagoshimensis cultivated in hanging nets than in those cultivated in cages on the seafloor and attributed this difference to buffeting of the suspended individuals by waves. Thus, the specimens from Locality 7 likely experienced less growth stress than those from Locality 1.

Acknowledgments We thank Kazuyoshi Endo, Toshihiro Kogure, Takanobu Tsuihiji, Hodaka Kawahata, Atsushi Suzuki, Toyoho Ishimura, and paleobiology seminar members of University of Tokyo for their suggestions on research methods and their comments; Yuji Kuyama, Makoto Fukui (Kudamatsu Institute of Mariculture, Yamaguchi Prefecture, Japan), and the other members of this institute; Shizuka Murakami (Kudamatsu City, Yamaguchi Prefecture, Japan), Hiroyuki Izumo (Miyagi Federation of Fisheries Cooperative Associations, Yuriage branch), and the other members of this association; Shoji Ohhasi (Nagasaki Prefecture Fisheries Technology Institute, Nagasaki Prefecture, Japan), Kei Senbokuya (Ishikawa Prefecture Fisheries Technology Institute, Ishikawa Prefecture, Japan), and the other members of these institutes for the donated specimens; and the members of FORTE Co. Ltd. for English editing. This study was supported by Mikimoto Fund for Marine Ecology and KAKENHI 24654167, 17K14413, 17J11417 funded by JSPS.

\section{References}

Carter JG (1980) Environmental and biological controls of bivalve shell mineralogy and microstructure, in skeletal growth of aquatic organisms: biological records of environmental change (topics in geobiology). In: Rhoads DC, Lutz RA (eds) Skeletal growth of aquatic organisms: biological records of environmental change. Plenum Publishing Corp, New York, pp 69-113

Carter JG (1990) Glossary of skeletal biomineralization. In: Carter JG (ed) Skeletal biomineralization: patterns, processes and evolutionary trends, 1. Van Nostrand Reinhold, New York, pp 609-661

Checa AG, Sánchez-Navas A, Rodríguez-Navarro A (2009) Crystal growth in the foliated aragonite of monoplacophorans (Mollusca). Cryst Growth Des 9:4574-4580

Checa AG, Bonarski JT, Willinger MG, Faryna M, Berent K, Kania B, González-Segura A, Pina CM, Pospiech J, Morawiec A (2013) Crystallographic orientation inhomogeneity and crystal splitting in biogenic calcite. J R Soc Interface 10:20130425

Currey JD (1976) Further studies on the mechanical properties of mollusc shell material. J Zool 180:445-453

Kennish MJ (1980) Shell microgrowth analysis: Mercenaria mercenaria as a type example for research in population dynamics. In: Rhoads DC, Lutz RA (eds) Skeletal growth of aquatic organisms: biological records of environmental change. Plenum Publishing Corp, New York, pp 255-294

Kennish MJ, Lutz RA, Rhoads DG (1980) Preparation of acetate peels and fractured sections for observation of growth patterns within the bivalve shell. In: Rhoads DC, Lutz RA (eds) Skeletal growth of aquatic organisms: biological records of environmental change. Plenum Publishing Corp, New York, pp 597-601

Kobayashi I (1976a) Internal structure of the outer shell layer of Anadara olluscani (Schrenck). Venus 35:63-72 (in Japanese)

Kobayashi I (1976b) The change of internal shell structure of Anadara ninohensis (Okuta) during the shell growth. J Geol Soc Jpn 82:441-447

Kobayashi I, Kamiya H (1968) Microscopic observations on the shell structure of bivalves-part III genus Anadara. J Geol Soc Jpn 74:351-362 (in Japanese with English abstract) 
Lutz RA, Clark GR (1984) Seasonal and geographic variation in the shell microstructure of a salt marsh bivalve (Geukensia demissa (Dillwyn)). J Mar Res 42:943-956

Nishida K, Ishimura T, Suzuki A, Sasaki T (2012) Seasonal changes in the shell microstructure of the bloody clam, Scapharca broughtonii (Mollusca: Bivalvia: Arcidae). Palaeogeogr Palaeoclimatol Palaeoecol 363-364:99-108

Nishida K, Suzuki A, Isono R, Hayashi M, Watanabe Y, Yamamoto Y, Irie T, Nojiri Y, Mori C, Sato M, Sato K, Sasaki T (2015) Thermal dependency of shell growth, microstructure, and stable isotopes in laboratory-reared Scapharca broughtonii (Mollusca: Bivalvia). Geochem Geophys Geosyst 16:2395-2408

Palmer AR (1983) Relative cost of producing skeletal organic matrix versus calcification: evidence from marine gastropods. Mar Biol 75:287-292

Sato K, Sasaki T (2015) Shell microstructure of Protobranchia (Mollusca: Bivalvia): diversity, new microstructures and systematic implications. Malacologia 59:45-103

Shimamoto M (1986) Shell microstructure of the Veneridae (Bivalvia) and its phylogenetic implications. Sci Rep Tohoku Univ Ser 2(56):1-39

Taylor JD, Layman M (1972) The mechanical properties of bivalve (Mollusca) shell structures. Palaeontology 15:73-87

Taylor JD, Kennedy WJ, Hall A (1969) The shell structure and mineralogy of the Bivalvia, introduction, Nuculacea-Trigonacea. Bull Br Mus Nat Hist Zool 22:1-125

Ubukata T (2001) Nucleation and growth of crystals and formation of cellular pattern of prismatic shell microstructure in bivalve molluscs. Forma 16:141-154

Yurimoto T, Nasu H, Tabase N, Maeno Y (2007) Growth, survival and feeding of ark shell Scapharca kagoshimensis with hung and settled culture in Ariake Bay, Japan. Aquaculture Sci 55:535-540 (in Japanese with English abstract)

Open Access This chapter is licensed under the terms of the Creative Commons Attribution 4.0 International License (http://creativecommons.org/licenses/by/4.0/), which permits use, sharing, adaptation, distribution and reproduction in any medium or format, as long as you give appropriate credit to the original author(s) and the source, provide a link to the Creative Commons license and indicate if changes were made.

The images or other third party material in this chapter are included in the chapter's Creative Commons license, unless indicated otherwise in a credit line to the material. If material is not included in the chapter's Creative Commons license and your intended use is not permitted by statutory regulation or exceeds the permitted use, you will need to obtain permission directly from the copyright holder.

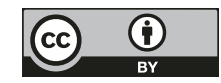

